\title{
The motivations and needs of rural, low-income household food gardeners
}

\author{
Kate J. Darby a * \\ Western Washington University \\ Taylor Hinton b \\ Allegheny College \\ Joaquin Torre ${ }^{c}$ \\ Western Washington University
}

Submitted September 14, 2018 / Revised January 8, March 12, and May 24, 2019 / Accepted May 27, 2019 /

Published online January 7, 2020

Citation: Darby, K. J., Hinton, T., \& Torre, J. (2020). The motivations and needs of rural, low-income

household food gardeners. Journal of Agriculture, Food Systems, and Community Development, 9(2), 55-69.

https://doi.org/10.5304/jafscd.2020.092.002

Copyright (C 2020 by the Authors. Published by the Lyson Center for Civic Agriculture and Food Systems. Open access under CC-BY license.

\begin{abstract}
In local food systems research and practice, little attention has been given to the motivations and behaviors of low-income household gardeners as food provisioners. In this paper, we examine the motivations, barriers, and practices of food
\end{abstract}

\footnotetext{
a * Corresponding author: Kate J. Darby, Department of Environmental Studies, Huxley College of the Environment, Western Washington University - MS 9085; 516 High Street; Bellingham, WA 98225 USA; darbyk@,wwu.edu

b Taylor Hinton, Environmental Science, Allegheny College; Meadville, PA 16335 USA.

Hinton is now at Secondary Education, Mercyhurst University; 501 East 38 ${ }^{\text {th }}$ Street; Erie, PA 16546 USA; taylor.r.hinton@gmail.com

c Joaquin Torre, Department of Communication Studies, College of Humanities \& Social Sciences, Western Washington University - MS 9162; 516 High Street; Bellingham, WA 98225 USA; Loaquin.torre@,wwu.edu
}

gardening among low- income rural U.S. residents with the goal of informing policies and programs that might support these food provisioning activities. This work draws from ethnographic inquiry, including surveys, interviews, and garden visits with households in rural, Western Pennsylvania. Over half of those surveyed $(n=124)$ grow some of their own food, with higher rates of gardening among higher-income households. Low-income gardeners are most motivated by three things; (1) a desire to save money, (2) pleasure from the practice of gardening and time spent outside, and (3) a connection to spiritual practice. For the low-income gardeners we interviewed, gardening creates and reinforces social connections and cultural

\section{Funding Disclosure}

This study was supported by funding from Allegheny College and Western Washington University's Huxley College of the Environment. 
traditions. For many, gardening is also a political act: a way to guard against an uncertain future and resist a centralized food system. The findings from this study suggest that local food systems programs and policies might better support low-income food-provisioning households by acknowledging and respecting the knowledge and skills held by these individuals, recognizing and supporting the social and cultural role of gardening, and providing structural support around the space and time concerns identified by survey respondents as major barriers to gardening.

\section{Keywords}

Household Gardening, Food Security, Rural, United States, Low-Income

\section{Introduction and Literature Review}

Research on household-level edible gardens has been limited and has tended to be directed towards the global South or community gardens in the North (Taylor \& Lovell, 2014). A recent surge of research has examined the role of urban household gardening (Gray, Guzman, Glowa, \& Drevno, 2014; McClintock, Mahmoudi, Simpson, \& Santos, 2016; Taylor \& Lovell, 2014), but rural gardening as a food-provisioning strategy in the United States remains understudied. Distinctions between rural and urban communities are messy and ill-defined in research and practice, ${ }^{1}$ yet the food systems literature gives little attention to the rural end of that spectrum. While claims have been made about the benefits of 'growing your own,' there is much less information as to the scale of food growing activity, particularly in relation to household gardens (Church, Mitchell, Ravenscroft, \& Stapleton, 2015). Moreover, there has been limited empirical analysis of the barriers that prevent participation in gardening and local food systems (Schupp, Som Castellano, Sharp, \& Bean, 2016). At the same time, household food-provisioning efforts across different geographic, economic, and racial contexts are building alternative food systems that — by design or in practice-disrupt an increasingly corporatized, neoliberal food system.

\section{Household Gardening in the U.S.}

Following Kortright and Wakefield (2011), we define home food gardens as "the use of private (owned, rented, or leased) land around a residence for growing edible produce" (p. 39). The National Gardening Association (2014) reports that onethird of U.S. households grew some of their own food in 2013, with a 17\% increase between 2008 and 2013 . Almost $30 \%$ of those households were located in rural areas (National Gardening Association, 2013). Household food gardening has a strong history in the U.S., including European settlers who grew their own food in kitchen gardens and the families who cultivated Victory Gardens during the World Wars. Oddly, the alternative food movement and local food movement have placed little emphasis on food gardening, despite it being a hyperlocal food production approach that has the potential to radically reconsider the relationship between people and their food (De Hoop \& Jehlicka, 2017; see also McEntee, 2010). The scarcity of literature regarding the barriers to household gardening is remarkable, considering how gardening has been proven to have great potential in improving social and ecological well-being for people and the food system in general (Colasanti \& Hamm, 2016; Kabir \& Webb, 2009; Mariola 2008).

Households are motivated to grow their own food for many reasons. For some, growing their own food is driven by desires to have produce that tastes better and is of higher quality (Kortright \& Wakefield, 2011; NGA, 2009). In their study of household gardeners, Kortright and Wakefield (2011) describe these as "cook gardeners"- those who grow food because they have an interest in producing high-quality ingredients for their meals. Kortright and Wakefield (2011) also describe "aesthetic gardeners"- those who grow edible plants because they add interest and beauty to their gardens, and not necessarily for the food they produce.

Although it is not a sole provider of food security, gardening has been shown to produce substantial amounts of food (Conk \& Porter, 2016;

\footnotetext{
${ }^{1}$ For example, U.S. governmental programs employ no fewer than fifteen different, and often conflicting, definitions of "rural" (Coburn, MacKinney, McBride, Mueller, Slifkin, \& Wakefield, 2007).
} 
Dewaelheyns, Lerouge, Rogge, \& Vranken, 2015; Kortright \& Wakefield, 2011). For example, a study in Laramie, Wyoming - a location with a challenging gardening climate-found that the average community garden plot (253 sq. ft. or 23 sq. m) provided enough food to meet the vegetable consumption requirements for an adult for 9 months (Conk \& Porter, 2016). In a case study in Flanders, researchers found that the average household garden produced $28 \%$ of household vegetables consumed (Dewaelheyns et al., 2015). Many households in the U.S. see growing much of their own food as a way to save money, especially during recessions (NGA, 2009).

Many studies have also identified physical and mental wellness, as well as the spiritual opportunity to connect and grow with nature, as benefits that stem from gardening and engaging with the outdoors (Duerden \& Witt, 2010; Freeman, Dickinson, Porter, \& van Heezik, 2012; Kjellgren \& Buhrkall, 2010). For some individuals, gardening serves as an important form of physical exercise. One recent study found that $42 \%$ of home gardeners in San Jose, CA, spent 1 to 3 hours a week gardening, and 21\% spent over 7 hours a week (Gray et al., 2014). Gardening may also promote a sense of mental wellness, and assertions of "ownership and identity" while providing an escape from the trappings of everyday life (Freeman et al., 2012). These motivations also point to gardening as a hobby from which individuals derive pleasure (Kortright \& Wakefield, 2011).

Gardening can also be a cultural and social practice. For many gardeners, growing their own food is a way to remain connected to their families and the communities around them (Freeman, 2012; Kortright \& Wakefield, 2011). Kortright and Wakefield (2011) identify "teaching gardeners" as those who are motivated to garden so that they may share the experience with their children and families. Gardeners may also be motivated by an interest in cultivating cultural practices (Dewaelheyns et al., 2015). For example, a study of urban gardens in Chicago found that the types of garden plants varied across gardens cultivated by African American, Chinese-origin, and Mexican-origin households. While gardens cultivated by African American households contained tomatoes and collard greens, Chinese-origin households had bitter melon and yardlong beans, and Mexican origin households had pápalo and hot pepper (Taylor, Lovell, Wortman, \& Chan, 2017). Gardening can also support cultural practices among immigrant families who may use the gardens to memorialize family, mimic landscapes of their home country, practice religion and spirituality, and/or grow plants with cultural significance (Mazumdar \& Mazumdar, 2012).

Finally, there are individuals who are motivated to garden by political and environmental considerations. For some, growing food is a way to guard against safety concerns about mass-produced food (NGA, 2009). In a Flanders study, researchers found that their study subjects saw gardening as a place to exercise control and choice and embrace a sense of "freedom" (Dewaelheyns et al., 2015). For many gardeners, growing their own food is an environmental or sustainability practice that reduces their ecological footprint and ameliorates some of the damage of an industrialized, corporate food system while also helping them connect more deeply with nature (Dewaelheyns et al., 2015; Freeman et al., 2012; Kortright \& Wakefield, 2011).

Despite the benefits and widespread practice of gardening, there are households that would like to garden but face barriers in doing so. For example, some studies have found low socioeconomic status (SES) to be a significant barrier to home gardening, as individuals and households living in poverty sometimes lack the financial resources to construct a garden and the time to cultivate it (DeLind, 2011; Hinrichs, 2000; Schupp et al., 2016). Moreover, geography can also be a barrier to home gardening. Where people live and the types of households that they occupy can influence how likely they are to garden. Those who own their homes and live in rural areas are more likely to garden than those who are tenants in urban areas (Church et al., 2015; Schupp et al., 2016). Those living in free-standing houses (rather than apartments or row-houses) were less likely to cite space as a barrier to gardening (Schupp et al., 2016). While the amount of space that one has to garden has been found not to be a determining factor, a household preference over how to use a potential gardening area can certainly influence whether one 
chooses to garden (Dewaelheyns et al., 2015; Kortright \& Wakefield, 2011). A study of youth community gardeners in Minneapolis-St Paul found that those youth who live in apartments saw that as a barrier to gardening at home (Lautenschlager \& Smith, 2007).

\section{Local Food Systems, Food Security, and "Traditional Localism"}

Local food system (or alternative food system) work responds to several current concerns, such as an increasingly corporatized and industrialized food system, food safety and sustainability, the prevalence of hunger and food insecurity, and cultural values around food production in the U.S. These efforts are often characterized by programs to connect food producers and consumers through community support agriculture mechanisms, farmers markets, and community gardens. Another surge of food systems work in the U.S. addresses concerns of food security, defined by the U.S. Department of Agriculture (USDA) as "access by all people at all times to enough food for an active, healthy life. Food security includes at a minimum: the ready availability of nutritionally adequate and safe foods, and an assured ability to acquire acceptable foods in socially acceptable ways (that is, without resorting to emergency food supplies, scavenging, stealing, or other coping strategies)" (USDA Economic Research Service, 2019, "What Is Food Security," para. 1-3). In 2017, 11.8\% of U.S. households were food insecure, and food insecurity rates tend to be higher in rural areas than in urban or suburban communities (ColemanJensen, Rabbitt, Gregory, \& Singh, 2018). Projects and policies to address food insecurity sometimes dovetail with local food systems projects, although these efforts often operate in tension. Some food systems scholars have argued that the alternative food movement efforts to bolster local food systems have not adequately involved low-income food consumers, nor considered their perspectives, knowledge, and needs in policy and programming (Dupuis \& Goodman, 2005; Hinrichs, 2000). Food justice scholarship activism suggest that many of these efforts only bring privileged individuals "into the foodshed" and that many local food systems projects neglect key questions of access, lack social embeddedness, and/or include the cultural appropriation of traditional food systems (Feenstra, 1997; Kloppenburg, Hendrickson, \& Stevenson, 1996). In summary, the proliferation of local food systems projects across the U.S. is likely not adequately collaborating with and meeting the needs of low-income communities.

At the same time, local food systems work has largely neglected household-level food gardening as a focus of support (Taylor \& Lovell, 2014). This is particularly true for gardening efforts aimed at lowincome residents. Despite all of this, there is evidence suggesting that low-income households frequently grow their own food and that doing so helps them address food insecurity and nutrition needs. A study of households in poverty in Iowa found that $29 \%$ of rural households had their own garden (Morton, Bitto, Oakland, \& Sand, 2008), and the NGA reports a $38 \%$ increase in gardening among households earning less than US $\$ 35,000$ a year between 2008 and 2013 (NGA, 2013). Regardless of household economic standing, a 2009 study by the NGA found that $60 \%$ of surveyed food gardeners said economic conditions had at least some impact on their decision to garden (NGA, 2013). A study in San Jose, CA, found that low-income household gardeners saved an average of US $\$ 339$ a season growing their own vegetables and that they met $60 \%$ of their dietary vegetable requirements through gardening (Algert, Baameur, \& Renvall, 2014). Similarly, in a study of rural low-income households, Morton et al. (2008) found that families with access to gardens were more likely to achieve nutritional goals for fruit and vegetable intake. In the Cuban context, household gardening has been used as a practice in resilience to socio-ecological change; although hunger is uncommon in Cuba, malnutrition levels are still quite high, and many Cuban residents turn to household gardening as a way to supplement food provided through ration cards (Buchman, 2009). This is not to say that households living in poverty easily make the choice to grow some of their own food. People in poverty may also face different sorts of trade-offs in choosing whether or not to garden. A study of Canadian farm women found that cost was a large barrier to these women growing more food for their own households, and 
especially the cost in preserving harvest for winter; also, these women already have high demands on their time, and many do not have time to process and grow more food for their own households despite a desire to do so (McIntyre \& Rondeau, 2011). Authors of a recent study on household food gardening in Ohio assert that "it is important to be attentive to the ways in which inequalities, such as those related to SES and housing type, impact the ability of individuals to participate in local food systems via home gardening" (Schupp et al., 2016, p. 763).

Thus, the study of behavior, motivations, and challenges of rural, low-income food gardeners remains a crucial subject that still requires significant attention. Two additional frameworks are useful in helping to understand the motivations of low-income, rural food gardeners: food sovereignty and McEntee's "traditional localism" (2010). Food sovereignty, a concept initially described by the international peasant movement La Via Campesina is described in the 2007 Forum for Food Sovereignty as "the right of peoples to healthy and culturally appropriate food produced through ecologically sound and sustainable methods, and their right to define their own food and agriculture systems" (Nyéléni, 2007, para. 3). Rural food gardeners may be motivated by a similar set of values and goals; in her 2012 article on framing food sovereignty, Madeleine Fairbairn suggests that food sovereignty can serve as a more radical, counterhegemonic approach than food-security framing and shares ideological grounding with extreme localism efforts, such as the Vermont secession movement. Similarly, many rural communities have pushed back on government regulations on milk pasteurization as a way to maintain their control over food systems and create what they see as a healthier dairy product.

McEntee (2010) argues that the most local food systems efforts are driven by "contemporary localism" - a set of ideologies around environmental protection, rural preservation, minimized food miles, and support of small farms. "Contemporary localism" is often represented by "alternative food initiatives" such as farmers markets, community supported agriculture, local food policy efforts, and fair-trade campaigns that do not reflect rural communities' experiences with or values of the local food system (McEntee, 2010). McEntee instead suggests that many rural households embrace a different set of ideologies in the form of "traditional localism," which "is instead guided by a motivation to obtain fresh and affordable food and/or to continue traditional modes of food production" (2010, p. 786). This "traditional localism" framework suggests that rural, lowincome gardeners may be driven by a different set of motivations than others engaged in local food systems efforts, and that food provisioning is less driven by environmental and political values than by concerns around food access and cost.

In this applied research effort, we examined these interrelated issues of socioeconomic class, food provisioning, and gardening through an ethnographic study in western Pennsylvania to better understand how and why low-income households grow their own food and what barriers they may face in doing so. This investigation was driven by a broader aim of better understanding the needs and challenges of low-income gardeners in order to better support their food-provisioning efforts, and to highlight the common motivations and concerns of these gardeners to inform food sovereignty-based coalition building.

\section{Applied Research Methods}

We conducted our ethnographic work in rural western PA, in and around the small town of Meadville. Founded in 1788 by David Mead, Meadville became a borough in 1823 and a city in 1866 as the Beaver and Erie Canal and the new railroads made it an important trade center. Twenty years later, Meadville became a prominent city, acting as the county seat within Crawford County. In many ways, Meadville reflects its rustbelt designation; the current population (about 13,000) is about $30 \%$ lower than the town's population peak $(18,972)$ in 1950 (U.S. Census, 1952; U.S. Census, n.d.-a). The poverty rate hovers around $24 \%$ (U.S. Census, n.d.-b). Meadville is a predominantly $(91 \%)$ white community (U.S. Census, n.d.c). Until the 1980s, Meadville was an industrial hub, hosting numerous tool and die shops along with other industrial sites. Most notably, Meadville claims to be the birthplace of the zipper and is the 
home of American Viscose, Talon, Dads Dog Food, and Channellock tools. Like other rustbelt communities, Meadville now struggles with its economic and cultural identity and faces serious financial constraints and depopulation. The combination of the rust belt and snowbelt status of this town is evident in the visual experience of declining housing stock. Many of the homes in Meadville-the same ones with large icicles in the winter indicating poor insulation, peeling paint, and sagging roofs-also host beautiful and prolific vegetable gardens. This is not surprising, since the region also has a rich agricultural heritage. Agriculture and gardening in Meadville benefit from the glacial till left by retreating glaciers 10,000 years ago. The region surrounding Meadville provides fertile farmland for the region's substantial Amish and Mennonite populations. The Meadville Market House, the longest continually operating market house in the state, hosts a weekly farmers market that draws producers and buyers from across the region. In the spring, the hardware and garden stores in town offer a dazzling array of gardening tools, soil amendments, seeds, and other items. According to U.S. Census categorization (based on population density, land use, and distance between population centers), Crawford County is predominantly rural (U.S. Census Bureau, n.d.-d). Our work grew out of an interest in understanding why people in our region, especially those whose time and financial resources seemingly are limited, grow their own food.

To approach our research goals, we developed a multimethod ethnographic research plan (Handwerker, 2001). This collaborative project drew from the work of undergraduate students at Allegheny College. The students codeveloped this research project with the faculty mentor/ instructor.

To develop culturally salient survey questions and to inform our inquiry, we began by investigating the literature to determine relevant areas of inquiry. We also conducted several unstructured interviews with gardeners to inform the response options on our survey instrument. From their responses and the limited literature on household gardening, we developed two survey instruments: one for respondents who currently grew some of their own food, and one for those who did not. The instrument included both open-ended and close-ended questions aimed at understanding gardening behaviors. It included questions about demographic characteristics that helped us identify participants in the second phase of the research. Undergraduate students at Allegheny College conducted surveys with 124 Meadville area residents (see Table 1). This survey effort aimed to achieve three goals: first, to better understand the prevalence, motivations, and practices of household gardening; second, to recruit participants for a more in-depth investigation; and third, as a learning experience for undergraduate research students. Before undergoing data collection, the students received training in survey techniques and research ethics. To achieve the dual pedagogical and methodological goals of the survey, we used a convenience sample to gather responses: students knocked on doors, stood at street corners, and attended community events in the spring and summer of 2012.

Drawing from our survey respondents, we recruited low-income households who garden to participate in a follow-up interview and garden visit, which we conducted in the summer of 2012. Because many practitioners and scholars view the federal poverty income level as well below a living income, our research follows the lead of many assistance programs in defining the experience of poverty as household incomes below $175 \%$ of the federally defined poverty line for 2011. In these visits with seven low-income households, we conducted lengthy semistructured interviews (Bernard, 2017) to better understand why and how these families garden. The interview protocol reflected our understanding of gardening motivations and

\section{Table 1. Survey Respondents by Gardening Status and Income Level $(n=137)$}

\begin{tabular}{lccc}
\hline & Low-Income & Higher-Income & Total \\
\hline Gardeners & 39 & 29 & 68 \\
\hline Non-Gardeners & 46 & 12 & 58 \\
\hline Total & 85 & 41 & 126 \\
\hline
\end{tabular}

Note: Not all respondents indicated their income level; low income is defined as below $175 \%$ of the federally defined poverty level. 
practices gleaned from the literature, as well as our interests in better understanding gardeners' needs. These visits also included a detailed set of garden observations, including measurements and photographs.

Using Microsoft Excel, a team of students and faculty cleaned the survey data and then analyzed the cleaned data using descriptive statistics. The authors analyzed the qualitative interview data through an inductive, iterative coding process to identify themes, points of consensus, and points of divergence in the responses (Creswell, 2009).

Given the nature of ethnographic research, this study's findings are not intended to be generalizable to all low-income, rural food gardeners, nor even to all low-income, rural food gardeners in our study community. Rather, the findings provide insights about gardeners' experiences and suggest some ways in which practitioners might better support and understand the needs and motivations of low-income, rural food gardeners.

This research was reviewed and approved by the institutional review boards at Allegheny College and Western Washington University. To protect participants' identity, we refer to individual respondents with pseudonyms.

\section{Results and Discussion}

The results of this study suggest that gardening is a prevalent behavior among the residents of Meadville, Pennsylvania. Of the 124 total survey respondents, $53 \%$ reported that they engaged in some type of fruit or vegetable gardening. Although gardening is a common activity across income groups, higher-income respondents in our study had higher levels of gardening $(69 \%)$ than lower-income respondents (46\%). The in-depth interviews and garden visits provided more details about the structure and content of home gardens. The gardens visited ranged from a small plot with a few tomato plants in the middle of town to a small field in a more rural setting. Tomatoes were the most common plant found in home gardens, with pumpkins, sunflowers, and squash also making an appearance in most gardens.

In our study population of gardeners in the Meadville, PA, area, edible food gardening is prolific, even among low-income household; Meadville area residents garden at higher rates (53\%) than the one-third estimated for the U.S. overall (NGA, 2013). Higher rates of gardening among higherincome households are also consistent with previous research, including a recent study in Madison, Wisconsin (Smith, Greene, \& Silbernagel, 2013).

\section{Gardening Motivations and Barriers}

The survey and interviews included questions about motivations and barriers to gardening. The survey responses from low-income participants who were not growing their own food offered insights about barriers to gardening for this group: $54 \%$ reported not having space to garden, 35\% reported not having enough time, and 20\% reported that their landlord does not allow gardening at their residence. Other reasons cited for not gardening included pet conflicts, a lack of need for additional produce, gardening not being worth it for just one person, poor soil quality, and a lack of interest. The survey results suggest that lower rates of food gardening among low-income households may be related primarily to a lack of space and time to do so. Schupp et al. (2016) found that space and housing type, as well as socio-economic status, affected households' gardening behaviors, with lower-income households, renters, and those in cities having a lower likelihood to garden than those living in apartments or row houses. A study in Portland, Oregon, also found homeownership to be positively correlated with gardening (McClintock et al., 2016). A lack of information or knowledge about gardening was rarely cited as a barrier to gardening, perhaps due to the rich agricultural history and the high rates of gardening in the region.

Motivations for gardening, as reported through the surveys, varied considerably across low-income and high-income gardeners (see Table 2). For lowincome participants, gardening is driven by economics and the enjoyment of gardening and the outdoors. Higher-income participants reported that they gardened because they enjoy the outdoors, appreciate the higher quality of produce, and find it relaxing. A recent study of household gardeners in Portland, Oregon, found that low-income households were more motivated to grow food in an effort to improve food security and save money, 
Table 2. Motivations for Gardening: Percentage of Gardeners Reporting these Factors among their Top Three Motivations

\begin{tabular}{|c|c|c|c|}
\hline \multicolumn{2}{|l|}{ Low-Income Gardeners ( $n=39$ ) } & \multicolumn{2}{|l|}{ Higher-Income Gardeners ( $n=29)$} \\
\hline Growing your own food is cheaper than purchasing it & $33 \%$ & You enjoy being outside & $33 \%$ \\
\hline You enjoy gardening & $26 \%$ & $\begin{array}{l}\text { The quality is better than what you can buy at } \\
\text { the grocery store }\end{array}$ & $33 \%$ \\
\hline You enjoy being outside & $21 \%$ & It's relaxing & $30 \%$ \\
\hline Gardening makes you feel more connected to God & $18 \%$ & You enjoy gardening & $26 \%$ \\
\hline $\begin{array}{l}\text { The quality is better than what you can buy at the } \\
\text { grocery store }\end{array}$ & $18 \%$ & It's better for the environment & $22 \%$ \\
\hline You can control what goes into your food & $18 \%$ & Gardening is good exercise & $19 \%$ \\
\hline Gardening is good exercise & $15 \%$ & You can control what goes in your food & $19 \%$ \\
\hline It's relaxing & $15 \%$ & Your family gardened when you were a child & $19 \%$ \\
\hline
\end{tabular}

while higher-income households were driven by environmental concerns (McClintock et al., 2016). These patterns hold true for our respondents, although the pleasure of gardening was a commonly cited motivation for all income groups in our study.

The semistructured interviews with lowincome gardeners added clarification and nuance to our understanding of gardening motivations. The pleasure and recreation provided by gardening were particularly salient to participants, who described great contentment with watching the fruits of their labor grow. John told us, "I enjoy sitting and looking at it once it's all planted and enjoy the view, watch everything grow from that little seed I think is quite interesting." Ethan described mindful contentment with gardening: "If you do it right you have your own food and that's really calming for a person, you know it's good

Table 3. How Did They Learn to Garden (all responses)

\begin{tabular}{lcc}
\hline & $\begin{array}{c}\text { Low-Income } \\
\text { Gardeners }(\boldsymbol{n}=39)\end{array}$ & $\begin{array}{c}\text { Higher-Income } \\
\text { Gardeners }(\boldsymbol{n}=\mathbf{2 9})\end{array}$ \\
\hline Parents & $74 \%$ & $68 \%$ \\
\hline Other Family & $54 \%$ & $46 \%$ \\
\hline Friends & $34 \%$ & $29 \%$ \\
\hline Master Gardeners & $6 \%$ & $4 \%$ \\
\hline Books & $43 \%$ & $43 \%$ \\
\hline Websites & $29 \%$ & $32 \%$ \\
\hline Other & $17 \%$ & $29 \%$ \\
\hline
\end{tabular}

health for a person's psyche." Participants also took great pride in the money-saving aspect of growing their own food. When asked why they garden, one participant said,

It's more economical-I doubt that we spend 20-25 dollars a week in the grocery store. You know, even in the wintertime. We buy the staples, but we just put a half a pork and a quarter of a beef in the freezer from the local slaughterhouse so we don't have to buy much.

The gardeners we interviewed were also acutely aware of external economic drivers of food and were using gardening as a buffer against them. Ellen pointed out that "the prices of tomatoes in the store are horrible. You pay like [US] $\$ 1.77$ a pound for vine tomatoes." Betty explained how her family was responding to current economic conditions: "Now with the economy, I'm gonna useI'm not gonna let anything go to waste. In fact, my husband put an ad in the paper asking for another pressure cooker canner and jars." For most of the gardeners we interviewed, putting up food (canning, freezing, dehydrating), was an important component of their food production.

\section{Knowledge and Practices}

Most of the surveyed participants across both income groups learned to garden from family (see Table 3). The gardeners we interviewed also emphasized the knowledge and skills gained from 
family members, especially around canning and food processing. Betty described how she learned to can from her mom, who "would can like 300 quarts of green beans and just huge amounts of things." Friends, books, and websites were other common sources of information about gardening. In our discussion with Betty, she told us about checking in with her neighbors for ideas to prevent worms in broccoli. While accessing other information sources, gardeners tend to rely on general web searches, as well as books from the Rodale and Better Homes and Gardens series. Several participants also mentioned referencing books about square foot gardening, as well as a print newsletter from the local garden store. In the "other" category, many cited "trial and error" or common sense, or previous experience as farmers or in school. In the interviews, the value of experimentation or trial and error emerged as an important form of gaining knowledge about growing food. John told us: "I have learned one thing, don't use horse manure 'cause it grows weeds really good."

Gardeners in the Meadville area employ a variety of common gardening techniques, including seed saving and composting (see Table 4). Very few respondents reported applying pesticides $(12 \%)$ or herbicides $(8 \%)$. In the interviews, gardeners explained why they choose certain techniques and opt against others. A majority of the gardeners interviewed cited concerns about the environment, human health, and sustainability as reasons they do not apply pesticides or herbicides. In the interviews, participants talked about how they preferred their own garden produce to vegetables they could purchase at the store because they knew that it was chemical-free. The idea of

Table 4. Common Gardening Techniques

\begin{tabular}{lcc}
\hline & $\begin{array}{c}\text { Number of } \\
\text { respondents }\end{array}$ & $\begin{array}{c}\text { Percentage of gardening } \\
\text { respondents }(\boldsymbol{n}=66)\end{array}$ \\
\hline Composting & 43 & $65 \%$ \\
\hline Seed-saving & 43 & $65 \%$ \\
\hline $\begin{array}{l}\text { Application of chemical } \\
\text { fertilizers }\end{array}$ & 23 & $35 \%$ \\
\hline Application of pesticide & 8 & $12 \%$ \\
\hline Application of herbicide & 5 & $8 \%$ \\
\hline
\end{tabular}

pesticide-, herbicide-, and synthetic fertilizer-free as "natural" was a common association; Betty told us that she switched back to manure from synthetic fertilizer because it "seems more natural, more healthy and it, you know, replenishes the soil." The participants also expressed a strong concern for ecological sustainability. For example, Jo spoke about letting the clover grow to "help the bees" because she has been seeing fewer of them. And Laura said that she "plants one for the rabbit, one for me. I don't like using sprays. I don't want the bug spray and stuff, poison."

\section{Cultivating Cultural, Social, and Political Meaning in Gardening}

The interview and survey data about where gardeners get information and learn to garden suggests that household-level gardening is a social practice. Our discussions with gardeners reinforce the cultural, social, and political meaning of gardening. For many of the gardeners we spoke to, gardening and food provisioning connects them more deeply to the place in which they live and to their land. Ethan suggested that gardening made him "force [him] self to be a part of a cycle" and told us that he "really like[d] experiencing the full lifecycle of a garden." Ellen described her experiences growing up in the Fifth Ward, a low-lying neighborhood in the floodplain of French Creek: "We hunted and fished a lot and ... we had frog legs all the time. And we had a trap line over on French Creek, which I walked with [my father] in the winter before I ever went to school." She also remembered foraging for wild horseradish with her parents.

Gardening connects individuals to their families and the people around them; as Fred said, "It's something that does tend to go with the people" and Ethan describes working on his uncle's farm as a youth as being a formative experience for him. For many of the gardeners, sharing garden produce and labor is a satisfying way to connect with friends and neighbors. Jo regularly puts a table of extra vegetables in front of her house and asks for donations, and John and Laura gave away their extra tomato seedlings to friends and neigh- 
bors. Ellen describes how her family shared tomatoes with the neighborhood kids growing up:

We had a long side porch on our house and when mama was done with all the tomatoes and we used what we could, that whole porch would be filled with tomatoes. We'd just go in and the neighbor kids were allowed. I got so many sores in my mouth [from eating tomatoes]!

Household gardens also often become places for neighborhood kids to connect and help out. As Fred told us, gardening "is a good way to connect with your neighbors - kids like to work in the garden." The social aspect of gardening that emerged from our interviews supports findings of other studies of low-income households who garden (either at their own home or at a community garden). For example, in a San Jose, CA, study of lowincome household garden projects, $30 \%$ of produce was given away to family and friends, and $80 \%$ of participants shared some food with neighbors (Algert, Baameur, Diekmann, Gray \& Ortiz, 2016; Gray et al., 2014). A study of Iowa households in poverty found that those living in rural areas were more likely to rely on a social safety net and reciprocity than to utilize redistribution (e.g., food stamps, other government or food bank support) (Morton et al., 2008). The social aspects extend beyond sharing food to sharing information and experiences as well. In this study, gardens seem to serve as a way to reinforce and value traditional ecological knowledge and knowledge exchange (see Buchmann, 2009). In urban settings, home gardens seem to contribute to a growing sense of community, with the majority of participants in a San Jose household garden program agreeing that the garden makes them feel part of a community, they made new friends in the program, and almost half met new neighbors through the program (Gray et al., 2014). This also seems to be the case in this rural context, where gardeners ask their neighbors and family for advice, support, and maybe a few extra tomato starts.

Although this study did not set out to examine gardening as a political act, most of the gardeners we interviewed framed growing their own food as just that — an act largely focused around issues of security and self-sufficiency. For many gardeners, producing their own food is a way to ensure that their family is independent and self-sufficient. For some gardeners, like Jo, this drive to self-sufficiency comes from concerns about the health of food from a conventional store: "it's just when you're using sprays and stuff on the ground, they can say what they want, even spraying the leaves, it's going into that product. I mean it's going into the vegetable ... and so therefore you're eating it." Similarly, Fred said, "I think there's a lot of problems with our kids with the stuff we're putting in their foods. Like meat, with the amount of steroids they're putting in meat, and we're wondering why our kids are having anger problems." For others, a desire for self-sufficiency stems from broader political or religious considerations about the instability of government and institutions. Betty described why she is dehydrating and putting up more food:

I'm a little nervous about our world and I've purposed to have a year's supply of food that we actually don't use but just have on hand in case anything happens. I mean, you can't hardly even turn on the TV without them mentioning something... I mean even if you just looked at the storms that just happened ... you wanna be responsible for yourself and your family, and that's why I'm dehydrating ... food will last longer. And I'm even buying things from the Amish ... a wheat grinder, a manual one.

On a follow-up visit, Betty showed us her freezer full of meat and a generator. In Jo's case, the concern around security and self-sufficiency connects to the notion of environmental collapse:

You know, we're destroying everything. I just read a documentary last night... plastic bottles ... this country only recycles $21 \%$ of their plastic bottles. The rest either goes in landfills or gets thrown on the ground and ends up in the sea ... They're saying that plastic can stay in the ground for 600 years before it actually breaks down ... Well, I think the Amish people and people like myself 
realize what's going on will be the survivors. We'll survive the longest, I'll put it that way. Cause we know what to do.

Paradoxically, these gardeners seem to value both the social experience of gardening and sharing food and labor, and also the individual and household security afforded by growing their own food.

For some of these households, gardening is a more radical act, a way to opt out of economic and governmental structures, or at least a way to address the failure of the market to provide food (see also Morton et al., 2008). In some cases, these concerns seemed to be tied to survivalist mentality, while others were more concerned about pushing up against impending environmental collapse. These political perspectives also suggest a challenge to the corporate food system and hint at values around food sovereignty (see also Alkon \& Mares, 2012).

Attitudes regarding household gardening among our study respondents seem to align with food sovereignty principles in three ways. First, our work suggests that gardening may foster knowledge systems and communities of informal resource exchange. Second, gardeners seem to be turning to gardening partially as a way to take control of what enters people's bodies and the environment. Finally, gardening provides a nonmarket-based approach to food production. Our findings also reinforce some aspects of McEntee's notion of "traditional localism" (2010), with gardening motivations being dominated by concerns around affordability and tradition. In our interviews, though, we also find that rural, low-income household gardeners express environmental values, and our survey findings suggest that these gardeners are largely motivated by maintaining control of what they eat. These findings suggest that rural household gardeners might also be influenced by underlying ideologies and political perspectives, and are not solely motivated by the cost of and access to produce.

This study provides insights about low-income, rural gardeners, although they are limited by the small sample size and limited geographic context. More qualitative, place-based studies like this are needed to understand how to better support gardening practice in diverse settings. We regret not directly interrogating several characteristics of gardeners, including homeownership, gender, cultural heritage, race, ethnicity, and religious affiliation, and suggest that future studies examine these issues.

\section{Implications for Practitioners}

At a follow-up visit by two of the authors, a husband and wife greeted us as old friends and immediately pressed two mason jars into my hands from their batch of apple syrup and canned peaches. They talked with pride about how they were able to provide for their family, cultivate a close connection to their food, and be self-sufficient. Gardeners like these represent an important component of food systems, and many opportunities exist to better support their provisioning efforts. Other scholars have pointed out that alternative food movements are missing out on connecting to home food producers (see De Hoop \& Jehlicka, 2017). Low-income, rural households in our study community value the practice of growing their own food, and doing so provides some sense of increased food security, as well as social, cultural, and political meaning.

The challenge, then, is to find ways to provide support while also acknowledging the tremendous knowledge and cultural value held by many of these communities in order to avoid falling into the information deficit falsehood. These survey results indicate that insufficient knowledge is not a barrier for household-level food provisioning, and the interviews expose the tremendous knowledge and capacity for experimentation held by low-income, rural gardeners. The most ubiquitous form of garden education and support (the Master Gardener program) is not frequently used by the households we surveyed, despite Pennsylvania's large network of volunteers and programs (Penn State Extension, n.d.). So, if these gardeners do not necessarily need more information or education, how can programs and policies better support their provisioning efforts?

The main barriers to gardening identified by gardeners in this study, space and time, are areas that programs and policies could address. For example, a food systems program might build rela- 
tionships with landlords and encourage creating lease language that allows gardening or might connect households with limited gardening space to neighbors who are willing to share gardening space. In an aging community like Meadville, creative solutions abound to connect retirees who are interested in gardening to households who are interested but lack the time to do so. These sorts of solutions build on the social value of gardening that emerged in our work. These findings also provide some ideas about how gardening programs might be marketed and framed for low-income, rural households. For example, the low-income gardeners we surveyed grow their own food largely because it saves them money, and they enjoy it. The spiritual value of gardening could also be supported by partnerships with churches and other religious groups. Although gardeners in this study sample possess gardening knowledge and skills, many expressed an interest in ecological issues, such as colony collapse disorder, so education programs aimed at these sorts of issues might be appealing to some low-income gardeners and serve as a way to draw these households to other programs.

This study's findings point to an opportunity to provide additional resources and support for household food production. While most food systems projects that focus on food productionespecially those aimed at low-income residentsprovide support for community gardens and farms, there is a growing set of programs and organizations that support household-level food production. For example, the La Mesa Verde program with University of California Cooperative Extension Master Gardeners Program in San Jose, CA, helps low-income residents grow their own food by providing free materials to build raised beds (Algert et al., 2016; Gray et al., 2014). After some initial challenges related to high drop-out rates and information-deficit-focused programming, the program shifted its approach, using social connections to help experienced gardeners in the program "train" new gardeners using a community-organizing model (Gray et al., 2014). It also moved from a

2 http://www.goodgrub.org/fig

3 http://www.backyardgrowers.org/backyard-gardens "needs-based model of service delivery" to an "assets-based model reflecting participatory development and local problem-solving approaches" (Gray et al., 2014, p. 195). Similar organizations dot the country: GrUB, ${ }^{2}$ a longstanding nonprofit in Olympia, WA, runs the Food Investment Garden (F.I.G.), which provides raised bed gardens to lowincome individuals on a sliding-scale fee schedule, with most low-income households qualifying for free garden construction. The Backyard Garden Program $^{3}$ in Gloucester, Massachusetts, provides free backyard raised beds, gardening materials (including seeds and seedlings), mentoring, and training to low-income households, with a modest sliding scale fee (US\$10-US\$50). The Garden Project, run by the Bellingham (WA) Food Bank, addresses the space challenge of low-income renter households by working with landlords and supporting gardens at public housing communities and a women's shelter.

The Meadville context suggests that practitioners focused on increasing small-scale food production face a missed opportunity for collaboration with others who share similar personal motivations and structural concerns about the U.S. food system. A few hundred miles west of Meadville, in the rustbelt city of Detroit, Michigan, food justice activists have been reclaiming vacant lots for agricultural production for decades, and the city serves as a "laboratory for urban farming" (Whitford, 2010, para. 24). For example, black women activists are growing food through the Detroit Black Community Food Security Network to provide healthy food for their families and to resist the decline of black community centers in the city (White, 2011). A study of urban agriculture participants in Detroit (including the following focus groups: black empowerment urban agriculture, community development urban agriculture, youth, and Hmong) found shared motivations and concerns around creating community, creating trust in the food system, and creating a more localized food system (Colasanti, Hamm, \& Litjens, 2012). While food provisioners and activists in Meadville and Detroit face some substantively different structural 
struggles - most notably, black activists in Detroit contend with the racism embedded in planning practices and many food systems programs in the city (White, 2011)—rural household gardeners and urban community gardeners share a desire to create new forms of social relations and food production in response to food systems that have left them out.

Since this research was conducted, a number of new food- and gardening-related programs have been developed in the Meadville area. New gardens are popping up all over the city. This is in part thanks to a new garden network, Grow Meadville, which has supported the development of and signage for 15 gardens in Meadville. Grow Meadville gardens range from traditional community gardens to school gardens, and to "city gardens," where local residents can freely pick produce grown in these spaces. Grow Meadville also runs a summer youth leadership program that has young people working in the garden, cooking with food from the garden, and working together to solve communitybased problems. The Mobile Market House began in 2017 and delivers affordable, local produce to low-income neighborhoods who may not otherwise access fresh food. Beyond Meadville, food practitioners from all over Northwest Pennsylvania are coming together to discuss community food systems and beginning to lay the groundwork for a stronger local food system.

\section{Acknowledgment}

We are grateful for the efforts of the environmental science students at Allegheny College who administered the surveys for this study.

\section{References}

Algert, S. J., Baameur, A., \& Renvall, M. J. (2014). Vegetable output and cost savings of community gardens in San Jose, California. Journal of the Academy of Nutrition and Dietetics, 114(7), 1072-1076. https://doi.org/10.1016/j.jand.2014.02.030

Algert, S. J., Baameur, A., Diekmann, L. O., Gray, L., \& Ortiz, D. (2016). Vegetable output, cost savings, and nutritional value of low-income families' home gardens in San Jose, CA. Journal of Hunger \& Environmental Nutrition, 11(3), 328336. https://doi.org/10.1080/19320248.2015.1128866

Alkon, A. H., \& Mares, T. M. (2012). Food sovereignty in US food movements: Radical visions and neoliberal constraints. Agriculture and Human Values, 29(3), 347-359. https://doi.org/10.1007/s10460-012-9356-z

Bernard, H. R. (2017). Research methods in anthropology: Qualitative and quantitative approaches (6 ${ }^{\text {th }}$ ed.). Lanham, Maryland: Rowman \& Littlefield.

Buchmann, C. (2009). Cuban home gardens and their role in social-ecological resilience. Human Ecology, $37(6), 705$. https://doi.org/10.1007/s10745-009-9283-9

Church, A., Mitchell, R., Ravenscroft, N., \& Stapleton, L. M. (2015). 'Growing your own': A multi-level modelling approach to understanding personal food growing trends and motivations in Europe. Ecological Economics, 110, $71-$ 80. https://doi.org/10.1016/j.ecolecon.2014.12.002

Coburn, A. F., MacKinney, A. C., McBride, T. D., Mueller, K. J., Slifkin, R. T., \& Wakefield, M. K. (2007, March). Choosing rural definitions: implications for health policy (Issue Brief No. 2). Rural Policy Research Institute Health Panel. Retrieved from http://rupri.org/Forms/RuralDefinitionsBrief.pdf

Colasanti, K. J. A., \& Hamm, M. W. (2016). Assessing the local food supply capacity of Detroit, Michigan. Journal of Agriculture, Food Systems, and Community Development, 1(2), 41-58. https://doi.org/10.5304/jafscd.2010.012.002

Colasanti, K. J. A., Michael W. Hamm, M. W., \& Litjens, C. M. (2012). The city as an "agricultural powerhouse"? Perspectives on expanding urban agriculture from Detroit, Michigan. Urban Geography, 33(3), 348-369. https://doi.org/10.2747/0272-3638.33.3.348

Coleman-Jensen, A., Rabbitt, M.P., Gregory, C.A., \& Singh, A.. (2018). Household Food Security in the United States in 2017, ERR-256, U.S. Department of Agriculture, Economic Research Service. Retrieved from https://www.ers.usda.gov/publications/pub-details/?pubid=90022.

Conk, S. J., \& Porter, C. M. (2016). Food gardeners' productivity in Laramie, Wyoming: More than a hobby. American Journal of Public Health, 106(5), 854-856. https://doi.org/10.2105/AJPH.2016.303108 
Creswell, J. (2009). Research design: Qualitative, quantitative, and mixed methods approaches ( $3^{\text {rd }}$ ed.). Los Angeles: SAGE.

De Hoop, E., \& Jehlička, P. (2017). Reluctant pioneers in the European periphery? Environmental activism, food consumption and "growing your own." Local Environment, 22(7), 809-824. https://doi.org/10.1080/13549839.2017.1289160

DeLind, L. B. (2011). Are local food and the local food movement taking us where we want to go? Or are we hitching our wagons to the wrong stars? Agriculture and Human Values, 28(2), 273-283. https://doi.org/10.1007/s10460-010-9263-0

Dewaelheyns, V., Lerouge, F., Rogge, E., \& Vranken, L. (2015). A different perspective on garden grabbing: Mapping the adaptive capacity of home food production. In M. Schrenk, V. V. Popovich, P. Zeile, P. Elisei, \& C. Beyer (Eds.), Proceedings of $20^{\text {th }}$ International Conference on Urban Planning, Region al Development and Information Society (pp. 13-30). CORP - Competence Center of Urban and Regional Planning. Retrieved from https://lirias.kuleuven.be/1742117?limo $=0$

Duerden, M. D., \& Witt, P. A. (2010). The impact of direct and indirect experiences on the development of environmental knowledge, attitudes, and behavior. Journal of Environmental Psychology, 30(4), 379-392. https://doi.org/10.1016/i.jenvp.2010.03.007

DuPuis, E. M., \& Goodman, D. (2005). Should we go "home" to eat?: Toward a reflexive politics of localism. Journal of Rural Studies, 21(3), 359-371. https://doi.org/10.1016/i.jrurstud.2005.05.011

Fairbairn, M. (2012). Framing transformation: The counter-hegemonic potential of food sovereignty in the US context. Agriculture and Human Values, 29(2), 217-230. https://doi.org/10.1007/s10460-011-9334-x

Feenstra, G. W. (1997). Local food systems and sustainable communities. American Journal of Alternative Agriculture, 12(1), 28-36. https://doi.org/10.1017/S0889189300007165

Freeman, C., Dickinson, K. J. M., Porter, S., \& van Heezik, Y. (2012). “My garden is an expression of me”: Exploring householders' relationships with their gardens. Journal of Environmental Psychology, 32(2), 135-143. https://doi.org/10.1016/j.jenvp.2012.01.005

Gray, L., Guzman, P., Glowa, K. M., \& Drevno, A. G. (2014). Can home gardens scale up into movements for social change? The role of home gardens in providing food security and community change in San Jose, California. Local Environment, 19(2), 187-203. https://doi.org/10.1080/13549839.2013.792048

Handwerker, W. P. (2001). Quick ethnography: A guide to rapid multi-method research. Lanham, Maryland: AltaMira.

Hinrichs, C. C. (2000). Embeddedness and local food systems: Notes on two types of direct agricultural market. Journal of Rural Studies, 16(3), 295-303. https://doi.org/10.1016/S0743-0167(99)00063-7

Kabir, M. E., \& Webb, E. L. (2009). Household and homegarden characteristics in southwestern Bangladesh. Agroforestry Systems, 75(2), 129. https://doi.org/10.1007/s10457-008-9142-5

Kjellgren, A., \& Buhrkall, H. (2010). A comparison of the restorative effect of a natural environment with that of a simulated natural environment. Journal of Environmental Psychology, 30(4), 464-472. https://doi.org/10.1016/i.jenvp.2010.01.011

Kloppenburg, J., Jr., Hendrickson, J., \& Stevenson, G. W. (1996). Coming in to the foodshed. Agriculture and Human Values, 13(3), 33-42. https://doi.org/10.1007/BF01538225

Kortright, R., \& Wakefield, S. (2011). Edible backyards: A qualitative study of household food growing and its contributions to food security. Agriculture and Human Values, 28(1), 39-53. https://doi.org/10.1007/s10460-009-9254-1

Lautenschlager, L., \& Smith, C. (2007). Beliefs, knowledge, and values held by inner-city youth about gardening, nutrition, and cooking. Agriculture and Human Values, 24, 245-258. https://doi.org/10.1007/s10460-006-9051-z

Mariola, M. J. (2008). The local industrial complex? Questioning the link between local foods and energy use. Agriculture and Human Values, 25(2), 193-196. https://doi.org/10.1007/s10460-008-9115-3

Mazumdar, S., \& Mazumdar, S. (2012). Immigrant home gardens: Places of religion, culture, ecology, and family. Landscape and Urban Planning, 105(3), 258-265. https://doi.org/10.1016/j.landurbplan.2011.12.020

McClintock, N., Mahmoudi, D., Simpson, M., \& Santos, J. P. (2016). Socio-spatial differentiation in the Sustainable City: A mixed-methods assessment of residential gardens in metropolitan Portland, Oregon, USA. Landscape and Urban Planning, 148, 1-16. https://doi.org/10.1016/i.landurbplan.2015.12.008 
McEntee, J. (2010). Contemporary and traditional localism: A conceptualisation of rural local food. Local Environment, 15(9-10), 785-803. https://doi.org/10.1080/13549839.2010.509390

McIntyre, L., \& Rondeau, K. (2011). Individual consumer food localism: A review anchored in Canadian farmwomen's reflections. Journal of Rural Studies, 27(2), 116-124. https://doi.org/10.1016/i.jrurstud.2011.01.002

Morton, L. W., Bitto, E. A., Oakland, M. J., \& Sand, M. (2008). Accessing food resources: Rural and urban patterns of giving and getting food. Agriculture and Human V alues, 25(1), 107-119. https://doi.org/10.1007/s10460-007-9095-8

National Gardening Association (NGA). (2014). Garden to table: A five year look at food gardening in America. Jacksonville, Texas: Author. Print copy available by contacting NGA's Garden Research division at https://gardenresearch.com/

Nyéléni. (2007). Declaration of the Forum for Food Sovereignty, Nyéléni 2007. Retrieved from http://nyeleni.org/spip.php?article290

Penn State Extension. (n.d.). Master Gardener Program: County highlights. Retrieved November 18, 2019, from https://extension.psu.edu/programs/master-gardener/about/impacts/2017-18-master-gardener-annualreport/county-highlights

Schupp, J. L., Som Castellano, R. L., Sharp, J. S., \& Bean, M. (2016). Exploring barriers to home gardening in Ohio households. Local Environment, 21(6), 752-767. https://doi.org/10.1080/13549839.2015.1017807

Smith, V. M., Greene, R. B., \& Silbernagel, J. (2013). The social and spatial dynamics of community food production: A landscape approach to policy and program development. Landscape Ecology, 28(7), 1415-1426. https://doi.org/10.1007/s10980-013-9891-z

Taylor, J. R., \& Lovell, S. T. (2014). Urban home food gardens in the Global North: Research traditions and future directions. Agriculture and Human Values, 31(2), 285-305. https://doi.org/10.1007/s10460-013-9475-1

Taylor, J. R., Lovell, S. T., Wortman, S. E., \& Chan, M. (2017). Ecosystem services and tradeoffs in the home food gardens of African American, Chinese-origin and Mexican-origin households in Chicago, IL. Renewable Agriculture and Food Systems, 32(1), 69-86. https://doi.org/10.1017/S174217051600003X

U.S. Census Bureau. (n.d.-a). Age and sex. 2010 American Community Survey: S0101. Retrieved November 18, 2019 from https://data.census.gov

U.S. Census Bureau. (n.d.-b). Poverty Status in the past 12 months of families. 2010 American Community Survey 5Year Estimates: S1702. Retrieved November 18, 2019, from https://data.census.gov

U.S. Census Bureau. (n.d.-c). Race. 2010 American Community Survey 5-Year Estimates: B02001. Retrieved November 18, 2019, from https://data.census.gov

U.S. Census Bureau. (n.d.-d). County rurality level: 2010. Retrieved November 18, 2019, from https://www2.census.gov > geo > docs > reference > County Rural Lookup

U.S. Census Bureau. (1952). U.S. Census of Population: 1950. Vol. I., Number of Inhabitants. Washington, D.C.: U.S. Government Printing Office, Retrieved from https://www.census.gov/prod/www/decennial.html\#y1950popv1

U.S. Department of Agriculture (USDA), Economic Research Service. (2019). Measurement. Retrieved from https://www.ers.usda.gov/topics/food-nutrition-assistance/food-security-in-the-us/measurement.aspx

White, M. M. (2011). Sisters of the soil: Urban gardening as resistance in Detroit. Race/Ethnicity: Multidisciplinary Global Contexts, 5(1), 13-28. https://doi.org/10.2979/racethmulglocon.5.1.13

Whitford, D. (2010, January 18). Can farming save Detroit? Fortune, 161(1), 79-84. 